\title{
THE STRATEGIC CONSEQUENCES OF INDIA'S COVID-19 CRISIS ON INDIA-CHINA TRADE AFTER GALWAN SKIRMISH
}

\author{
Dr. Anita Kumari \\ Assistant Professor, Department of Commerce, Dr. Harisingh Gour Vishwavidyalaya, Sagar, M.P
}

Article DOI: $\underline{\text { https://doi.org/10.36713/epra8462 }}$

DOI No: 10.36713/epra8462

\begin{abstract}
The magnitude of the second one wave of India's coronavirus surge became an increasing number of clear to the world, U.S. policymakers soon started to comprehend the strategic implications of India's national trauma.U.S. President and his top officials publicly pledged their commitments to ship medical supplies, which include oxygen, vaccine materials, and therapeutics to India, while looking for additional approaches to deal with India's crisis. COVID-19 already inflicted a crushing blow to India's economy closing 12 months. A countrywide lockdown instituted via prime Minister Narendra Modi at the early levels of the worldwide pandemic was meant to alleviate the stresses on Indian's insufficient healthcare system, however it also brought a 24 percentage contraction in the economy and led millions of migrant day workers to flee India's towns for lack of work. thru the late fall and wintry weather, it seemed that by some means India might break out the worst of the pandemic, but that hope has now been dashed by a devastating combination of new viral strains and inadequate public health preparations. India now faces this wave of the virus exhausted and depleted.China-India relations, also referred to as Sino-Indo relations or Indian-chinese relations, refers back to the bilateral relationship between the humans's Republic of China and the Rebublic of India. despite the fact that the relationship has been cordial, there were border disputes. The current relationship started out in 1950 whilst India turned into many of the first countries to end formal ties with the Republic of China (Taiwan) and understand the human beings's Republic of China because the valid government of Mainland China. China and India are the two of the principal regional powers in Asia, and are two of the most populous countries and quickest growing primary economies in the global. boom in diplomatic and financial influence has increased the importance of their bilateral courting.
\end{abstract}

KEY WORDS: India, China, Magnitude, China-India trade, trade warfare, composition of economy,

\section{INTRODUCTION}

India was famed for her excellent wealth ever since the historical instances till the establishment of the British Empire. Indian trade records reflects that in spite of the frequent political upheavals during the twelfth to the sixteenth centuries, the country was still prosperous. The political and financial rules followed through the Muslim rulers propagated the growth of towns in various parts of the country. these towns grew into exchange and business centers which in flip led to the general prosperity. From the sixteenth to the 18th centuries, covering the two hundred years of Mughal rule, Indian urbanization saw in addition growth.India and China are among the oldest civilizations of the international with lengthy history of interaction and courting. They are the fastest growing economies amongst the major economies of the world. both have made fast progress after liberlisation. One of the primary occasions in worldwide trade and economics is the latest fast increase in the bilateral change. India has emerged as one of the top ten trading partners of China while China has emerged one of the pinnacle 3 trading partners of India. Due to big size of economies and composition of economies and exports as well as high boom rates and political will from each facets, the bilateral trade will develop further and would have vast effect on global alternate and economic system As border tensions between India and China flared up with the deadliest clash in more than four decades, leaving at least 20 Indian soldiers dead, there have been calls for boycotting goods imported from the 
neighbouring nation. That, however, won't be easy because the two economies are intertwined.China is Asia's largest economy and the world's second-biggest with a GDP of about \$13.6 trillion. India is No. 3 in Asia at \$2.7 trillion. From supplying industrial components and raw materials to investments in India's startups and technology firms, China is India's biggest trading partner after the U.S.The magnitude of India's crisis turns it into a worldwide disaster. With over 1.3 billion people, India alone counts for one-sixth of humanity. And India's crisis will not be contained within its borders. New viral lines out of India should worsen the health threat to all. different secondorder economic effects will observe; a minimum of, India's lost monetary productiveness will hurt worldwide trade and investment.yet the geopolitical implications of India's tragedy must additionally be keenly felt by using the new Biden management. After his election, the president's top national security officials quickly established the aim of closer partnership with New Delhi as a cornerstone in the U.S. strategy for competition with Beijing. India's position was highlighted with the aid of President Biden's choice to host a virtual "leaders' summit" of the Quad in March, and by U.S. Secretary of defense Lloyd Austin's 3-day visit to India shortly thereafter.Having made a strategic bet on India as an essential Asian counterweight to China, U.S. concerns about Indian health, economic growth, and political balance are not purely altruistic or humanitarian. As some of distinguished Indian foreign policy analysts observed in the days earlier than the Biden administration announced its plans to help India, the promise of U.S. partnership might be significantly undermined from India's attitude if Washington had been to fall short in such a time of need.inside the midst of immense suffering, it is tempting to count on that India's state of affairs could not worsen. but, the truth is that India become already going through an entirely different, daunting danger to its country wide safety previous to this new viral wave: a year of heightened tensions and unusual levels of violence along its contested border with China. most of the causes of deteriorating family members between India and China stay unaddressed. the two sides have taken some initial steps to disengage from their border conflict inside the Himalayas in early 2021, however in latest weeks their bilateral army dialogues have stalled without progress. If Beijing were to are looking for a territorial advantage from India's ongoing health emergency, the compounding of multiple crises could complicate New Delhi's decision-making and would increase the potential for policy miscalculations and otherwise avoidable armed escalation.An argue in an replace of an earlier CFR Contingency making plans Memorandum at the chance of armed war between China and India, the us has a strong interest in preventing navy escalation alongside their border. through carefully calibrated protective help to India, the united states can help it deter China with out taking steps that make battle more likely. other diplomatic and financial measures can enhance India's defenses and resilience in the face of chinese aggression, reduce regional tensions, and prepare U.S. policymakers in the event of another Himalayan standoff this year

\section{OBJECTIVE OF STUDY}

The goal of the observe is to consciousness on the impact of COVID-19 second wave on various sectors of the economic system. The sectoral evaluation has also helped to compare the beyond consequences with the existing scenario and also analyse the state of affairs winning in the country in phrases of losses and possibility prices. The main objective of this paper is to have a look at the spillover results Indo-china trade war on the economic system amongst diverse markets and sectors mentioned as follows:

\section{Chinese Investments in India}

- Chinese Hooks In India's Startups

- The Smartphone Dominance

- Chinese Smartphone applications

- Pharmaceutical Sector

- India-China Tourism

Spurred to an extent by India importing medical items from China to fight the deadly second wave of the Covid-19 pandemic, trade between the two neighbours soared by more than $70 \%$ year-on-year to over $\$ 48$ billion within the first five months of 2021, China's customs data showed.

Calling it a "impressive growth", chinese state media interpreted the increase in bilateral trade as a sign of resilience in trade ties between the two nations despite conflict at the border and political variations. "Trade among China and India soared $70.1 \%$ in US greenback terms in the first five months of this year to $\$ 48.16$ billion, in line with chinese customs records released on Monday. specially, chinese exports to India grew $64.1 \%$ year-on-year from January to may, while imports surged $90.2 \%$," the tabloid global times reported.The India-China trade volume changed into better than the trade that Beijing conducted with different trading partners, the report said.The paper 
also highlights the impact on GDP.foreign direct investments from China come to metallurgical industries, renewable energy (solar panels), electric device, automotive and chemical substances.data compiled via BloombergQuint from China global investment Tracker confirmed chinese language FDI into India at \$4.14 billion in 2019. China's commerce ministry, but, pegs the figure at at \$eight billion for 2018-19.consistent with invest India, there are roughly 800 chinese language companies in the domestic market. have more or less 75 manufacturing facilities for smartphones, purchaser home equipment, production system, electricity tools, automobiles, optical fibre, and chemical substances.

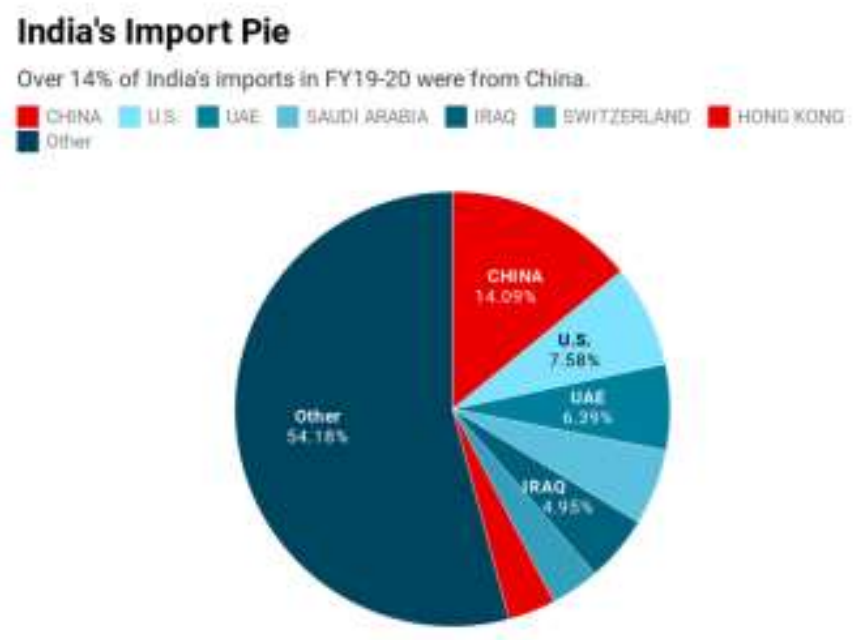

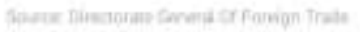

\section{India-China Trade}

China accounted for over 5\% of India's total exports in monetary year 2019-20 and more than $14 \%$ of imports. that means, India runs a huge trade deficit with China, the largest exporter to India.

absolutely the cost of imports from our neighbour may additionally have fallen, their share within the typical pie rose from $13.68 \%$ inside the preceding financial. India, in keeping with state-backed invest India data, is the 7th largest export destination for chinese products. chinese exports to India include smartphones, electrical appliances, power plant inputs, fertilisers, car components, finished steel products, capital items like power plants, telecom equipment, metro rail coaches, iron and metal products, pharmaceutical elements, chemical compounds and plastics and engineering goods, amongst other things, according to the Ministry of commerce.

India's imports from China jumped forty five times since 2000 to reach over $\$ 70$ billion in 2018-19, in keeping with invest India.

\section{India-China Trade}

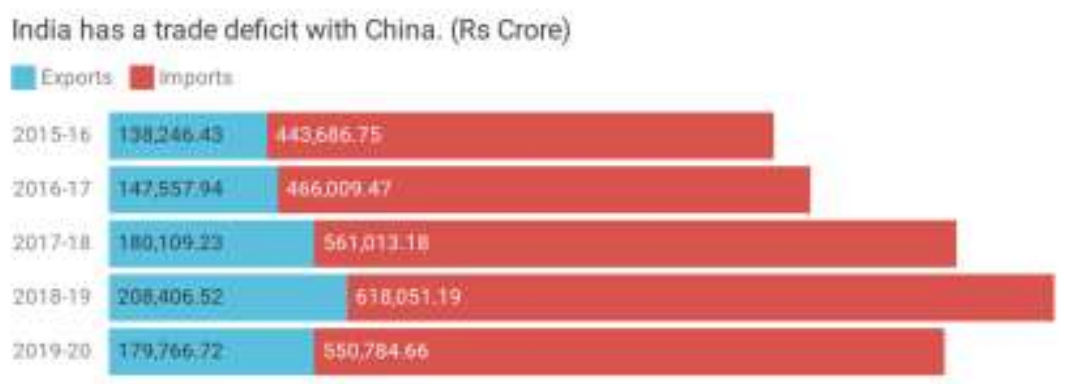


Financial impact of India-China warfare: Why there won't be just one loser

The financial interdependence of the two neighbours is just too deep to be overlooked

India and China's business interests are deeply intertwined and any adverse scenario will have far-reaching impact on both the countries As tensions simmer at the border between India and China, what is more concerning is the economic fall out of the souring relationship between the two countries. This is because the economic interdependence of the two neighbours is too deep to be ignored.China and the US are the largest two trading partners of India. While Indian exports to the US outnumber the imports from the country, the same is not true when it comes to China. And hence, to become friends-turned-foes with India would have business repercussions in China, too.

\section{India's top trading partner}

For the period among April 2019 and February this year, China accounted for 11.8 per cent of India's overall imports. but, India's overall exports to the country was a mere 3 per cent. honestly, we purchase more from China than we sell. This alternate deficit with China, also a chief contributor to India's ordinary trade deficit, is one of the world's largest trade deficits between countries

The deficit with China stood at $\$ 3.3$ billion in February, a 13 per cent rise from the year-ago period. this is at the same time as India's typical trade deficit remained flat from a year in the past at $\$ 9.8$ billion.

however, bilateral trade has reduced drastically over the last two months due to each the pandemic and the rising cold vibes between the nations. earlier, on Tuesday, the Confederation of All India traders (CAIT) released a listing of 500 categories of products imported from China that it stated could be swapped with items made in India. CAIT wants to bring down the imports from China to $\$ 13$ billion by December 2021 from $\$ 70$ billion in 2018-19. It said it plans to do so by substituting a list of goods imported from China with local goods.

\section{What India imports from China?}

India's imports from China rose from 13.7 per cent in 20-18-19 to 14.1 per cent in 2019-20. India's major imports from the neighbour include engineering goods, electronics, pharmaceuticals and automobile components. At a complete price of over $\$ 18$ billion, electronic imports formed a quarter of the whole imports in February. Nuclear reactors, equipment and parts comprised another predominant chunk of the imports at $\$ 12$ billion.

\section{What India exports to China?}

India's exports to China rose from 5.1 per cent in 2018-19 to 5.3 per cent in 2019-20 (until February). Organic chemical, ores, slag and ash, and mineral oils, mineral fuels and other industry products comprise India's exports to the country.

Despite the total value of India's exports growing by nearly half between 2010 and 2019, the sum going to China shrank 14 per cent over the period, deepening a trade deficit that's fueling India's nationalistic turn.

\section{India's Export Pie}

China is the third-largest export manket for Indian goods as of FY19-20

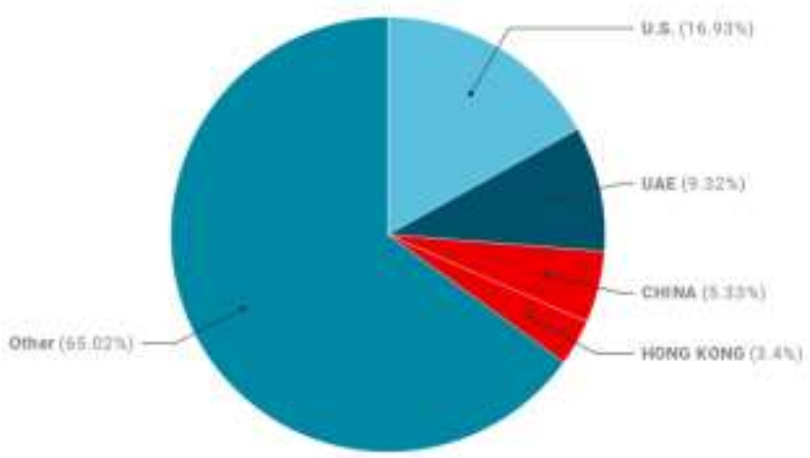




\section{Chinese FDI to India}

The numbers clearly show India's heavily reliance on Chinese imports and any disruption of trade ties between the two countries will substantially hurt Indian businesses.

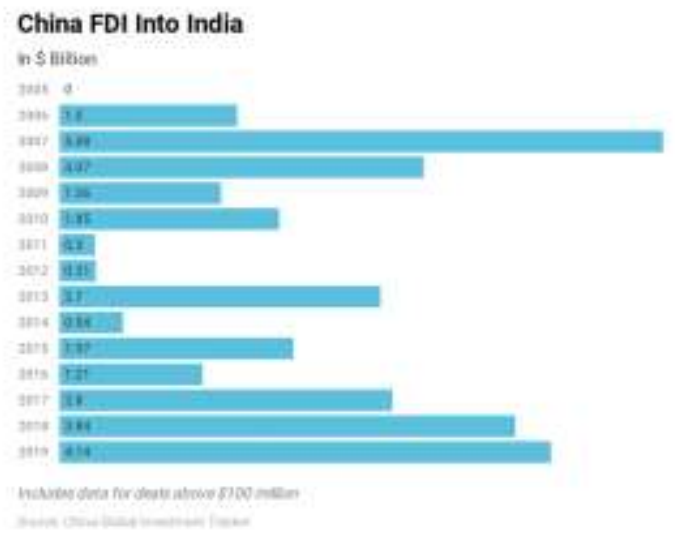

Alibaba, for example, has invested in Indian e-commerce company Snapdeal, digital wallet Paytm and food delivery platform Zomato. Tencent, meanwhile, has backed Indian messaging company Hike and ride hailing app Ola. Gateway House found that more than half of India's 30 unicorns - private firms worth more than $\$ 1$ billionhave Chinese investors.

Meanwhile, India changed its FDI policy in April soon after the People's Bank of China decided to up its stake in India's HDFC bank to over 1 per cent. As per the tweak, neighbouring nations can invest in Indian firms only after getting the Centre's approval for the same.

China retaliated saying India's new policy violated WTO's principle of non-discrimination and are against the general trend of free trade.

And Huawei is still in the running to help build 5G networks in India's fast-growing internet economy, despite a US-led campaign against the Chinese company. The Indian government has already started mulling amending the latest telecom tenders to cause a body blow to Huawei. According to various reports, more such measures will follow.

China's Xiaomi leads the India smartphone market with 30 per cent market share, followed by Vivo, Samsung, Realme and Oppo.

To be sure, several large Chinese companies spanning handsets, electronic devices and internet firms are deeply invested in India's consumer market where a fast growing middle-class and an aspirational young consumer base has helped propel the growth for companies such as Xiaomi Corp, BBK Electronics that owns brands such as Oppo, Vivo, among others; apart from electronics goods company TCL. India's emergence as the biggest overseas market for Chinese mobile phone companies is one of the most significant developments in China's relations with India over the past five years..

The Chinese smartphone makers have already built factories and created jobs in India. Interestingly, these smartphone makers have embraced Prime Minister Narendra Modi's "Make in India" programme. Xiaomi locally manufactures 95 per cent of the phones it sells in India. And hence, any adverse announcements forcing Chinese businesses to shut shop in India will add to the burgeoning unemployment rates in India.

While it is widely perceived that India might be most impacted economically in case of a conflict with China, the latter, too, will lose a significant and perhaps, one of the most easily accessible markets. Hence, China will stand as much to lose as India.

The Smartphone Dominance

Chinese smartphones brands, led by Xiaomi, Vivo and Oppo, are market leaders in India with an estimated 72\% share put together, leaving Samsung and Apple behind, according to a report by Gateway House. Quarterly data by Counterpoint corroborates this. 


\section{Chinese Brands Dominate}

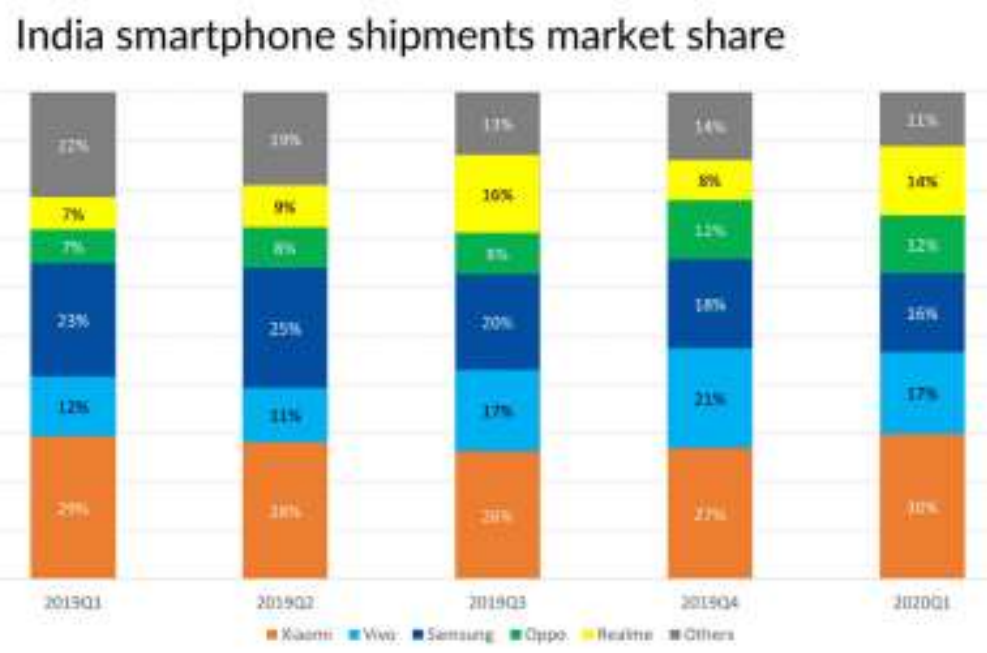

Source: Counterpoint

\section{Chinese Hooks In India's Startups}

Chinese funds and companies often route their investments in India through offices located in Singapore, Hong Kong, and Mauritius, a Gateway house report said.for example, Alibaba organization's investment in Paytm came via Alibaba Singapore Holdings Pvt. those don't get recorded in India's authorities information as chinese investments, the record said. "In several instances, the investment in India hasn't been made in the name of the chinese entity/investor, and is, therefore, difficult to trace.chinese tech investors have put an estimated $\$ 4$ billion into Indian startups, according to the report. As of March 2020, 18 of India's 30 unicorns are chinese-funded. 


\section{INDIAN UNICORNS WITH CHINESE INVESTORS \\ Note: These startups may also have other investors.}

\begin{tabular}{|c|c|c|}
\hline Brand & Chinese investors & $\begin{array}{l}\text { Estimates Imve } \\
\text { Millior }\end{array}$ \\
\hline Bigbasket & Albaba Greup, TR Capital & $>250$ \\
\hline Byjus & Tencent Holdings & 250 \\
\hline Delhivery & Fosun & $>25$ \\
\hline Dream 11 & $\begin{array}{c}\text { Steadview Capitat, Tencent } \\
\text { Holdings }\end{array}$ & $>150$ \\
\hline Flipkart & $\begin{array}{c}\text { Steadview Capital, Tencent } \\
\text { Holdings }\end{array}$ & $\$ 300$ \\
\hline Hilke & Tencent Holdings, Foxconn & $>150$ \\
\hline MakeMy Trip & Ctrip & \\
\hline ola & $\begin{array}{l}\text { Tencent Hoidings, } \\
\text { steadview Capital, Sailing } \\
\text { Capital and China, Eternal } \\
\text { Yield International Ltd. } \\
\text { China-Eurasian Economic } \\
\text { Cooperation Fund. }\end{array}$ & $>500$ \\
\hline Dun & Didi Chuxing, China & \\
\hline
\end{tabular}

Sourcing Bulk Drugs

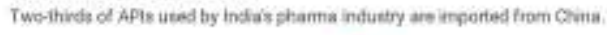
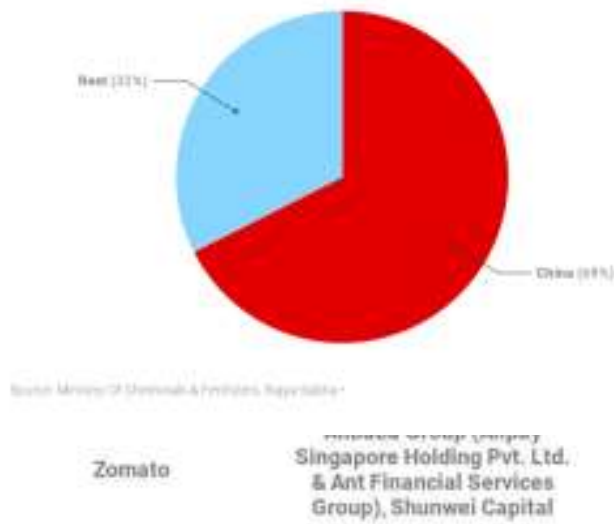

$>200$

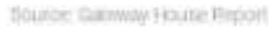

India's Dependence On China For Bulk Drugs:

India's pharmaceutical industry is the $1 / 3$ biggest in the world in with the aid of volume and ranks 14 by way of value. The country exported medicines well worth over \$14 billion to the U.S. in 2018-19, according to a reaction to a question within the Rajya Sabha in March. 
however, consistent with the equal respond, India imports two-thirds of its lively pharamaceutical substances, or key elements of medicine, from China.

\section{India-China Tourism}

travel between India and China has been growing. Or at least it become earlier than the Covid-19 pandemic.

Mainland China become the eighth-biggest market for India in 2018 with almost 3\% percentage in total arrivals. From just 1,371 arrivals in 1981, the number rose to 2.8 lakh in 2018, growing at an annualised price of 32 .four\%, according to information available with the Tourism Ministry of India. nearly $48 \%$ of the arrivals were for business purposes, and some other $48 \%$ for leisure.

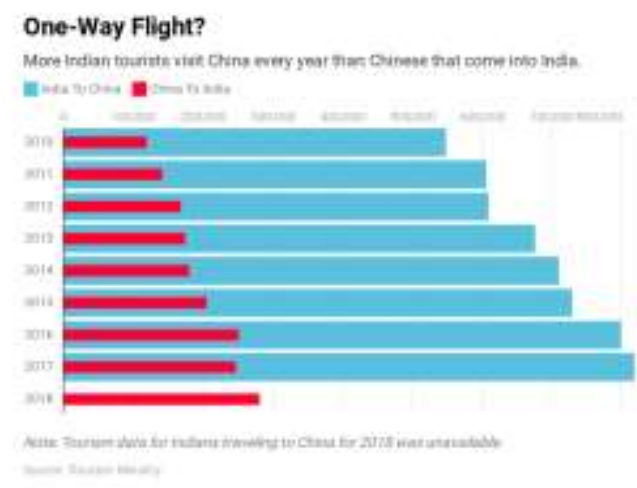

\section{CHALLENGES \& OPPORTUNITIES}

\section{Its implications on markets Negative Implications}

Chinese products form a critical part of the supply chain for firms in many sectors in India. With the economy struggling to recover from the pandemic, any potential escalation between the two nations could escalate operational as well as supply-chain risks. India can look to find alternatives for Chinese products but such a step would be tedious and expensive.

Another Key sectors affected would be :

Consumer Durables: India is heavily dependent on China for components for consumer durables.

Auto: China is a key supplier of sub-components used in the engine, electronics, tires, etc

Telecom: China caters to a majority of smartphone demand in India and even globally. Therefore, any disruptions will result in a spike in smartphone prices and probably lead to a delay in the adoption of new technologies such as $5 \mathrm{G}$.

Power: India imports a vast portion of its solar modules from China.

Chemicals and agrochemicals: The Indian agrochemical industry imports a high amount of raw materials from China.

\section{Positive Implications:}

This could be a great opportunity for startups in India to rise up to the occasion and build products and services for making India more self-dependent. Key infrastructure products allotted to Chinese firms could also come to Indian firms as a result of this escalation.

\section{CONCLUSION}

India and China are the two fastest growing economies among the major economies of the world. Both countries have shown remarkable growth after liberlisation process. One of the recent and more important aspects is the bilateral trade between the two countries. The bilateral trade has grown remarkably in the last seventeen years. Today China is one of the top three trading partners of India whereas India has become one of the top ten trading partners of China. Looking at the size of the economy, composition of economy and exports and growth rates, there is a lot of untapped potential for bilateral trade growth. This bilateral trade will have significant impact on the global trade and economic scenario.Trade War With 
China Not Good Idea Given India's Manufacturing Ability.Instead of 'Boycott China', the call should be to develop our own domestic industry and compete naturally.The clamour for boycotting Chinese products amid Indo-China tensions is unrealistic.Trade Promotion Council of India (TPCI), which is plays a key role in assisting the government in policies matter. As a trade and investment promotion. The anti-Chinese sentiments are not in the economic interest of the country if one is looking at the current reality,

\section{REFERENCES}

1. https://www.bloombergquint.com/amp/economy-finance/six-things-to-know-about-india-china-economic-relations

2. https://indianexpress.com/article/opinion/columns/coronavirus-impact-on-economy-recession-job-loss-covid-19-sajjidz-chinoy-6416299/litel

3. https://www.theweek.in/news/biz-tech/2020/06/18/economic-impact-of-india-china-conflict-why-there-wont-be-justone-loser.amp.html

4. https://www.outlookindia.com/website/amp/india-news-trade-war-with-china-not-good-idea-given-indiasmanufacturing-ability-trade-promotion-body/354952 